OPEN ACCESS

Edited by:

Gail Schofield,

Queen Mary University of London,

United Kingdom

Reviewed by:

Thomas A. Jefferson,

Clymene Enterprises, United States

Phil Clapham,

Seastar Scientific Inc., United States

Daniel Pike,

Esox Associates, Canada

*Correspondence:

Russell Fielding

rfielding@coastal.edu

tThese authors have contributed equally to this work and share first

authorship

Specialty section:

This article was submitted to

Marine Megafauna,

a section of the journal

Frontiers in Marine Science

Received: 16 February 2021

Accepted: 24 March 2021

Published: 14 April 2021

Citation:

Fielding R and Kiszka JJ (2021) Artisanal and Aboriginal Subsistence Whaling in Saint Vincent

and the Grenadines (Eastern

Caribbean): History, Catch

Characteristics, and Needs

for Research and Management.

Front. Mar. Sci. 8:668597.

doi: 10.3389/fmars.2021.668597

\section{Artisanal and Aboriginal Subsistence Whaling in Saint Vincent and the Grenadines (Eastern Caribbean): History, Catch Characteristics, and Needs for Research and Management}

\author{
Russell Fielding ${ }^{1 * t}$ and Jeremy J. Kiszka ${ }^{2 \dagger}$ \\ ${ }^{1}$ HTC Honors College and Center for Interdisciplinary Studies, Coastal Carolina University, Conway, SC, United States, \\ ${ }^{2}$ Institute of Environment, Department of Biological Sciences, Florida International University, North Miami, FL, United States
}

Whaling has been a contentious international environmental issue for decades and carries complex ecological and socioeconomic implications. In Saint Vincent and the Grenadines (SVG), a small archipelagic nation located in the Eastern Caribbean, presentday whaling traces its origin to local interaction with American-based whalers during the nineteenth and early twentieth centuries. When American whaling in the region ceased, local shore-based whaling arose to fill the niche and to exploit the remaining, though diminished, stocks of large whales, as well as stocks of small cetaceans that the American whalers had not targeted as heavily. After a period of expansion throughout the late nineteenth and early twentieth centuries, which saw shore-whaling operations established on at least 11 islands in the region, Eastern Caribbean whaling experienced a period of attrition, during which most local whaling operations ceased. Two operations, both based in SVG, continue regularly today. This paper reviews the past and present status of whaling activities in SVG from the literature and using recent data collected from 2007 to 2017 through logbook data, interview surveys, and ethnographic observations. Small cetacean captures have been documented since 1949, and at least 15 species of odontocetes have been captured (primarily delphinids). From 1949 to 2017, a total of 13,856 small cetacean captures has been recorded, including 5,896 shortfinned pilot whales (Globicephala macrorhynchus), 109 killer whales (Orcinus orca), and 7,851 other small cetaceans. Small cetacean catch records are largely incomplete and total catch estimates could not be attempted. Reliable abundance estimates do not exist. Consistent records for the take of large whales are only available for the period 1986-2020, during which 45 humpback whales (Megaptera novaeangliae) and 2 Bryde's whales (Balaenoptera edeni) were taken. Additionally, 8 sperm whale (Physeter macrocephalus) captures were reported from 1967 and 1974. We also review 
whaling practices, existing national policy on whaling, management techniques outside of formal policy regimes, research needs, and future management perspectives. Future monitoring and management of whaling activities in SVG are strongly needed to assess the sustainability of small cetacean exploitation.

Keywords: baleen whales, Caribbean Sea, cetacean consumption, delphinids, Globicephala macrorhynchus, hunting, Orcinus orca

\section{INTRODUCTION}

Marine mammal consumption is widespread around the globe, with at least 114 countries involved since 1990 (Robards and Reeves, 2011). Despite a decline of marine mammal consumption and killing globally, there is evidence that small cetacean hunting has increased, particularly in the production of "marine bushmeat" in a number of developing nations (Clapham and Van Waerebeek, 2007; Cosentino and Fisher, 2016). The sustainability of small cetacean consumption and killing is unknown for most locations around the globe, since takes tend to occur in relatively remote locations or where research capacity is limited.

In 1946, the International Whaling Commision (IWC) was established to regulate commercial whaling. From its inception, the IWC recognized the different character of aboriginal subsistence whaling, which it set out to manage differently (Reeves, 2002). In 1981, the IWC defined "aboriginal subsistence whaling" as whaling "for purposes of local aboriginal consumption carried out by or on behalf of aboriginal, indigenous or native people who share strong community, familial, social and cultural ties related to a continuing traditional dependence on whaling and on the use of whales" (Donovan, 1982). Currently four countries have permission from the IWC to practice aboriginal subsistence whaling: Denmark, Russia, Saint Vincent and the Grenadines, and the United States. Small cetacean (Delphinidae and Phocoenidae) hunting is not regulated by the IWC, and the authority of the IWC to regulate takes of small cetaceans is not generally accepted (Gillespie, 2001). "Artisanal whaling" is not a term used by the IWC but, following Reeves (2002), we can adapt the term based on the definition of "artisanal fisheries" used by the Food and Agriculture Organization of the United Nations (FAO). Artisanal whaling thus involves individuals and small groups (as opposed to commercial companies) using small amounts of capital and energy, relatively small vessels, making short trips close to shore to take cetaceans for local consumption. Both aboriginal subsistence whaling and artisanal whaling occur today and have occurred in recent years throughout the world, along with other forms of whaling (Robards and Reeves, 2011).

The archipelagic, Eastern Caribbean nation of Saint Vincent and the Grenadines (SVG) maintains two related, yet distinct whaling operations. The first, based in the village of Barrouallie on the leeward (west) side of the main island, St. Vincent (Figure 1), targets small cetaceans such as short-finned pilot whales (Globicephala macrorhynchus), killer whales (Orcinus orca) and other small and medium-sized odontocetes (Delphinidae, Kogiidae; Caldwell and Caldwell, 1975; Fielding, 2018). The second whaling operation, based on the island of Bequia, targets humpback whales (Megaptera novaeangliae) during their annual migration from their summer feeding grounds in the North Atlantic (Swartz et al., 2003; Stevick et al., 2018). The main product of both operations is food for human consumption, specifically meat, blubber, and some internal organs (Fielding, 2018; Fielding et al., 2021). Oil is also produced in both operations and is used locally as an oral and topical medicine, for cooking, and for other household purposes. Both whaling operations are legal and regulated by Vincentian law (SVG, 2003).

Although cetaceans (particularly small odontocetes) have been hunted for many decades off St. Vincent, little is known about the sustainability of artisanal whaling in this region, and how whaling might impact species and populations in the Eastern Caribbean. Overall, knowledge of cetacean occurrence, habitat preferences, and abundance in this region is very limited (but see Gero et al., 2007; Gero and Whitehead, 2016; Barragán-Barrera et al., 2019). There is also a critical need to understand the movements and population structure of cetaceans in the region, particularly to assess the regional impact of the Vincentian whaling on small cetaceans in the Eastern Caribbean and beyond (IWC, 2019). This is particularly important in light of the development of multiple local and international research and conservation initiatives focused on cetaceans in the Caribbean, and the need to identify the conservation issues and management needs for cetaceans in this region.

Very limited research has been carried out to describe whaling activities in Saint Vincent and the Grenadines, including its history, whaling practices and methods, and the magnitude of catches (species composition and numbers, but see Caldwell and Caldwell, 1975; Price, 1985; Fielding, 2018). Recent research, however, suggests that high levels of mercury in small cetacean tissues may represent a risk to the health of cetacean-product consumers in SVG (McCormack et al., 2020; Fielding et al., 2021). Here we review all available information documented since 1949 on whaling practices in SVG, with a special focus on small cetacean hunting using the available literature (18812020) and field data collected from 2007 and 2017, where whaling activities have been the focus of a dedicated multi-year research program.

\section{METHODS}

\section{Review of the Literature and Published Catch Data}

We surveyed the peer-reviewed and gray literature on whaling in the Caribbean generally, and in SVG in particular, published 


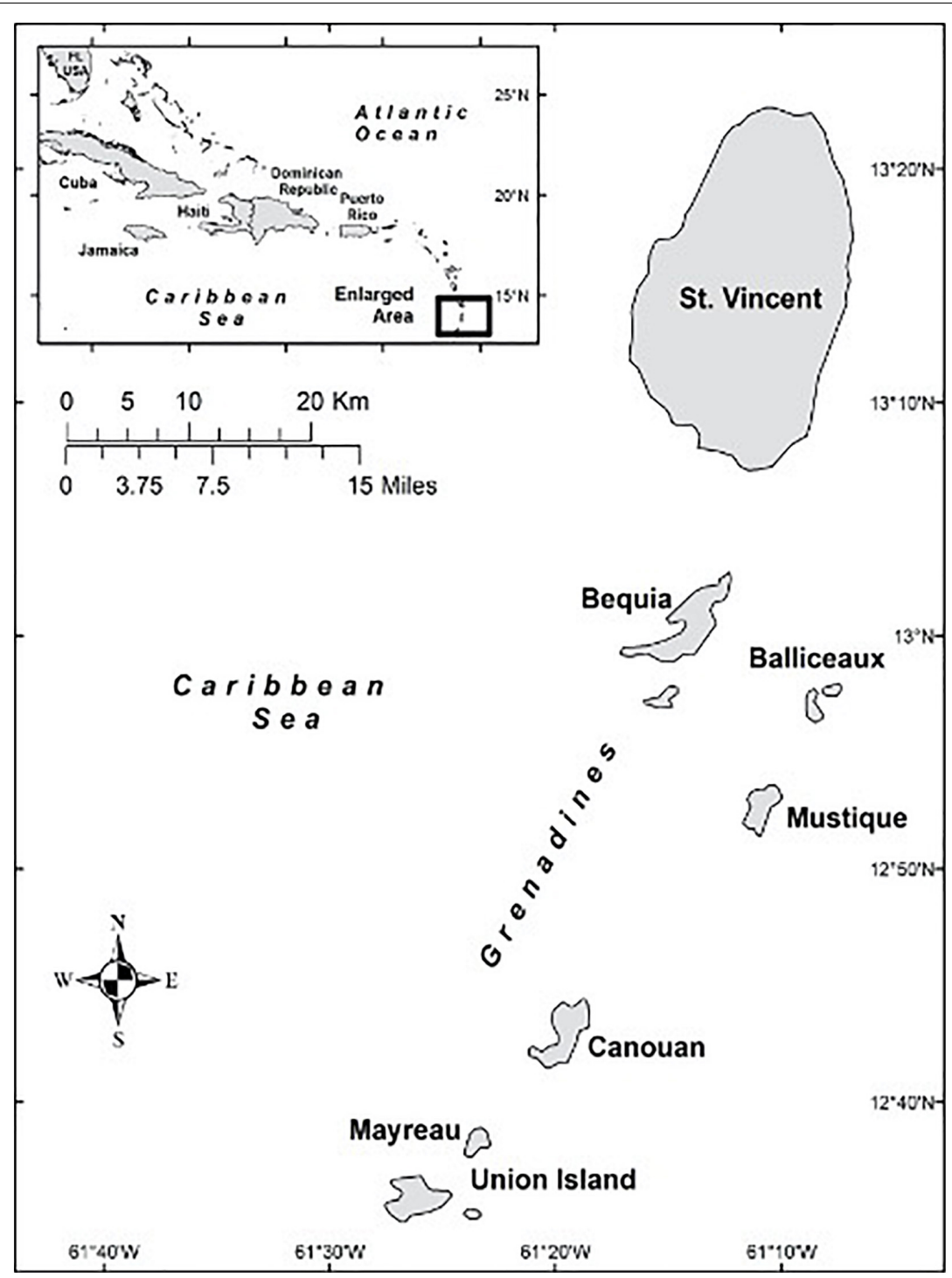

FIGURE 1 | Location of Saint Vincent and the Grenadines, Eastern Caribbean Sea.

between 1881 and 2020. Catch data are available in the literature starting in 1949 (Hickling, 1950), but were mostly available from 1962 onward (e.g., Caldwell and Caldwell, 1975). A few anecdotal accounts of captures of killer whales in 1994, 1996, and 2000 were also compiled and included in the review of catch records (Bolaños-Jiménez et al., 2014). Some sources were available as citations on literature search engines, but the published documents were unavailable. Hard copies were collected in all cases. In addition, reports of the IWC were searched between 1971 and $2020^{1}$. Large whale catch records were obtained from the IWC's aboriginal subsistence whaling records from 1986 to $2020^{2}$.

${ }^{1}$ https://iwc.int/reports

${ }^{2} \mathrm{https} / / /$ iwc.int/table_aboriginal

\section{Data Collection (2007-2017)}

In 2007, one of the coauthors (RF) initiated a field project aimed at collecting information on whaling practices and small cetacean catch composition from the main whaling village on St. Vincent, Barrouallie (Figure 1). From 2008 to 2017 (except in 2013 and 2014), at least annual site visits to St. Vincent were carried out, ranging in duration from a few days to 3 months. A total of 10 separate trips were made during this period. Throughout most of this period, 3-5 whaling boats operated from Barrouallie, each with a rotating crew of approximately 12 whalers, meaning that the total number of whalers in Barrouallie was between 36 and 60 during this study. Each boat is owned by one individual; some boat owners work aboard their own boats, usually as captain and harpooner, but some owners do not participate in whaling activities directly. Four whalers were interviewed 
repeatedly during this 10 -year period and whaling activities were observed primarily during a 3-month period of participant observation working aboard the whaling boats during the fall of 2009, and augmented by several shorter periods of observation afterward. In addition, fifteen formal interviews were conducted with stakeholders including whalers $(n=7)$, a vendor $(n=1)$, fisheries cooperative employees $(n=3)$, government fisheries officers $(n=2)$, international anti-whaling activists $(n=3)$, and local researchers $(n=2)$. Longer, more frequent, informal interviews with whalers, consisting of lengthy, casual conversations, occurred during periods of downtime while whaling, on days when the weather precluded going to sea, or with whalers who stayed ashore on days when their colleagues were at sea. Regardless of the formal or informal nature of the interviews, meticulous field notes were taken. When researchers were absent from the field site, communication with whalers and other local experts was maintained via email and online messaging. Field methods also included dietary surveys among potential whale-based food product consumers in the general public ( $n=921$, see Fielding et al., 2021); archival research; and tissue sample collection for ecotoxicological analysis (see McCormack et al., 2020). Whaling methods were investigated through interview surveys with whalers, archival research, and field observations.

Small cetacean catch data were also collected from 2007 to 2017 (except in 2013 and 2014). At the commencement of fieldwork, catch records only went back 1 year. Observations of all boats' catches during the first years of the project indicated that one particular boat regularly took twice as many small cetaceans as the rest of the fleet combined. The owner of this more prolific boat was also the only whaling boat owner in Barrouallie who keeps reliable catch records in a logbook. Data from this whaler were collected each year and compiled. In the logbook, each line represents 1 day and entries are made for the number of "blackfish" (usually G. macrorhynchus, the main target species) taken, the number of "porpoise" (various Delphinidae species) taken, and the number of "killer whales" (O. orca) taken. Financial data are also recorded, including daily expenses and wholesale prices obtained for cetaceans on shore. During field seasons, we would photograph the monthly pages of the boat owner's record books back to where our records had left off the previous time. Hand-written data were transcribed into a spreadsheet, in which monthly and annual totals were calculated. Species identifications have only been possible opportunistically, and therefore the species composition of cetaceans taken is not available.

\section{CARIBBEAN WHALING HISTORY}

Indigenous communities throughout the Caribbean basin relied heavily upon marine resources during pre-Columbian times (Sauer, 1966; Wing and Reitz, 1982; Fitzpatrick and Keegan, 2007). In addition to the fish, shellfish, and sea turtles taken by indigenous islanders, marine mammals such as manatees and seals were also hunted for food (McKillop, 1985; McClenachan and Cooper, 2008). The continued exploitation of these vulnerable species into the colonial era drove the Antillean manatee (Trichechus manatus manatus) to local extinction in the waters surrounding most Caribbean islands, and the Caribbean monk seal (Monachus tropicalis) to total extinction during the twentieth century (Le Boeuf et al., 1986; Gómez et al., 2011).

Little is known about the use of cetaceans by pre-Columbian insular Caribbean communities, with most of the literature suggesting that the direct exploitation of cetaceans did not occur prior to the arrival of Europeans in the region, except perhaps through the use of stranded animals (Reeves, 2002; Fitzpatrick et al., 2008). The presence of cetacean bones at archeological sites (e.g., Wing and Reitz, 1982; Romero and Cresswell, 2005) indicates only that the animals were utilized by humans and cannot readily evince whether they originated from naturally stranded animals that were scavenged for food and other resources or if the animals were actively hunted. Most Caribbean archeologists tend to accept the former explanation for the presence of cetacean bones in Caribbean middens (Fitzpatrick et al., 2008), while others (Wing and Reitz, 1982) point to the presence of tools with at least the potential for use in whaling as evidence of some kind of directed take. The single, dubious, historical claim of a European observation of indigenous whaling in practice from the wider Caribbean region traces to Acosta (2002 [1590]), who bases his account on what "some expert men have told me" (p. 149), and involves a method of whaling unknown elsewhere and uncorroborated locally in which whales were taken off the coast of Florida by the plugging of their blowholes with stakes. Acosta's story was popularized by True (1904), whose book is often cited for this likely untrue account.

Acknowledging the unlikelihood, though not the complete elimination, of the possibility that some direct, pre-Columbian exploitation of living, free-swimming cetaceans occurred in the Eastern Caribbean, we place the beginning of Caribbean whaling in the mid-eighteenth century, when so-called Yankee Whalers began visiting the area. Reeves (2005) and Romero (2012) cite primary and secondary sources of ships' logs related to whaling voyages in the Bahamas, the French West Indies, Barbados, and other islands of the Eastern Caribbean between 1750 and 1775. An earlier source, cited by Starbuck (1878) and Romero (2012), indicates an interest in Caribbean whaling among "twelve whalemen" led by one Timotheus Vandernen, who sought permission in August 1688 from Sir Edmund Andros, then governor of New York, to pursue, in the brigantine Happy Return, "a fishing Design about the Bohames [Bahamas] Islands and Cap florida for sperma Coeti [sperm] whales" (Physeter macrocephalus). Starbuck could not determine whether or not this "fishing design" ever took place, but it revealed to him the existence of whaling knowledge in the American colonies prior to the eighteenth century. This source also reveals a desire to put that whaling knowledge into practice, specifically in the Caribbean region. The year 1762 is the earliest year cited by a reputable source (Starbuck, 1878) for whaling taking place actually within the Caribbean basin, as opposed to nearby areas such as the Bahamas and Florida. Reeves (2005) cites the end of Yankee whaling in the area as occurring sometime during the 1920s and Romero (2012) identifies the 1921 departure of the 
TABLE 1 | Small cetacean species diversity, relative occurrence (common, regular, rare) in captures in Saint Vincent and the Grenadines (1949-2017), and their IUCN Red List Conservation Status.

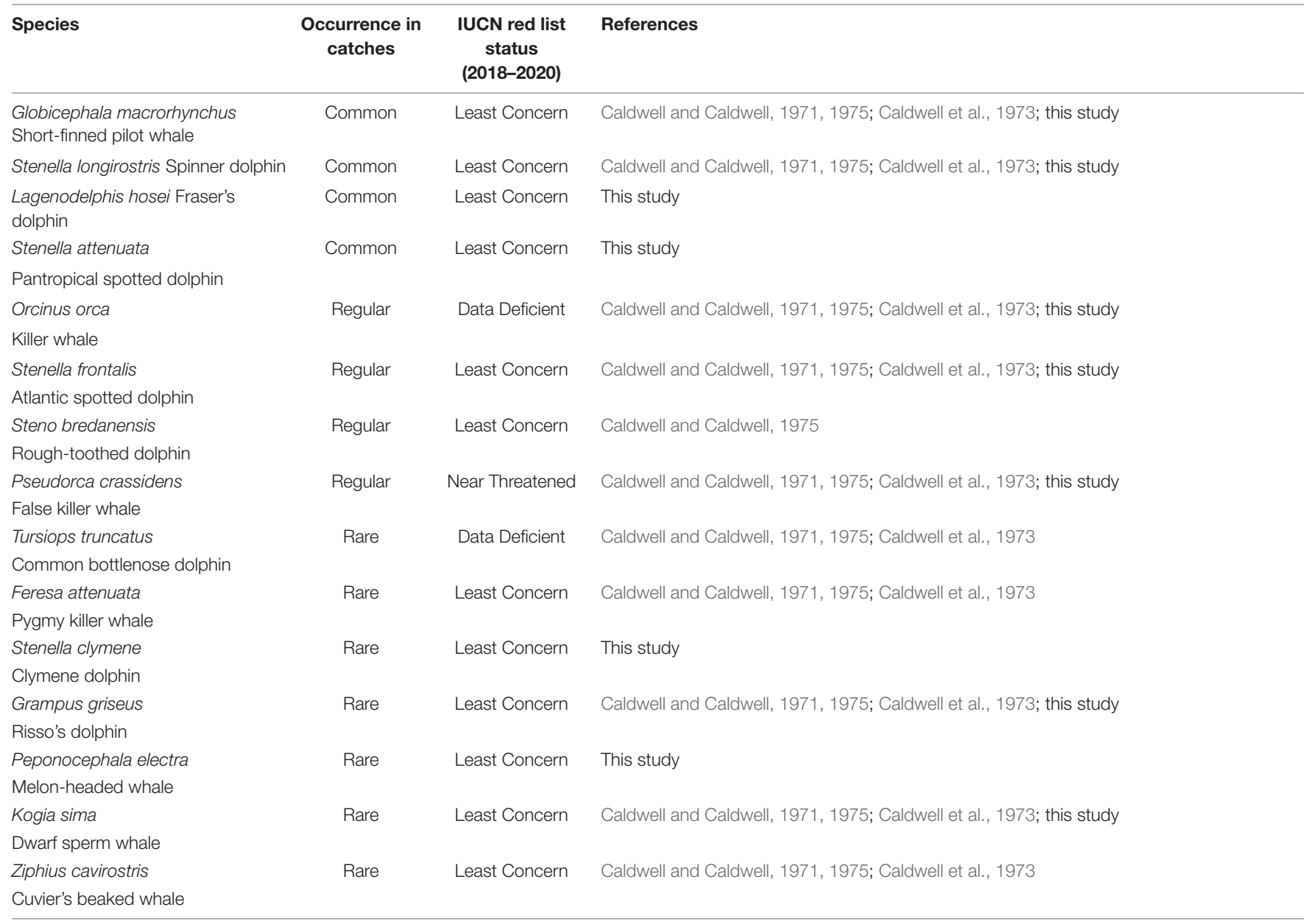

New Bedford-based whaling schooner Athlete from St. Thomas in the US Virgin Islands as the last of the era.

Beginning, then, at least by 1762 , and continuing until 1921, American vessels took whales within the Caribbean, often calling at island ports for provisions, supplies, and personnel (Starbuck, 1878; Brown, 1945; Adams, 1971; Price, 1985; Reeves, 2005; Romero, 2012). New England captains soon found that local Caribbean men, "half castes from all parts of the West Indies and of Central America" as one twentieth century economist derisively called them (Brandt, 1940), could perform the same labor as their American counterparts, but for much lower wages. Through this hiring of local labor, the transfer of the knowledge, skills, and practice of whaling from foreign to domestic control began. Capacity having been built, locally managed whaling operations began to arise in Barbados (Archer, 1881; Romero and Cresswell, 2010) and Bequia (Fenger, 1917; Ward, 1995) during the late nineteenth century. Bequia emerged as the center of Caribbean whaling and from this entrepôt, the model of shore-based whaling stations targeting mainly humpback whales spread to at least 11 islands throughout the region (Brown, 1945; Adams, 1971; Fielding, 2018).
Parallel to the development of these operations, and also drawing upon skills transferred through interactions with American commercial whaling, the exploitation of small cetaceans ranging in size from spinner dolphins to killer whales, but increasingly focused upon short-finned pilot whales, emerged throughout the region at varying degrees of regularity ranging from occasional and opportunistic to regular and direct (Adams, 1973). While small cetaceans previously had been taken occasionally and opportunistically by Barrouallie-based whalers and fishers, the regular, directed take of small cetaceans began there in 1931 (Adams, 1973).

After expanding throughout the early twentieth century, the spread of locally directed, shore-based whaling operations for humpback whales in the Eastern Caribbean began to decline. Today, owing to this attrition, the small port village of Paget Farm on Bequia remains the only place in the Caribbean from which large whales are hunted. Small cetaceans are taken primarily from Barrouallie, on St. Vincent, and occasionally from several ports on St. Lucia (Price, 1985; Fielding, 2018). The Bequiabased operation targeting humpback whales is IWC-sanctioned as aboriginal subsistence whaling, the only such case in the tropics and a subject of continual international and national 


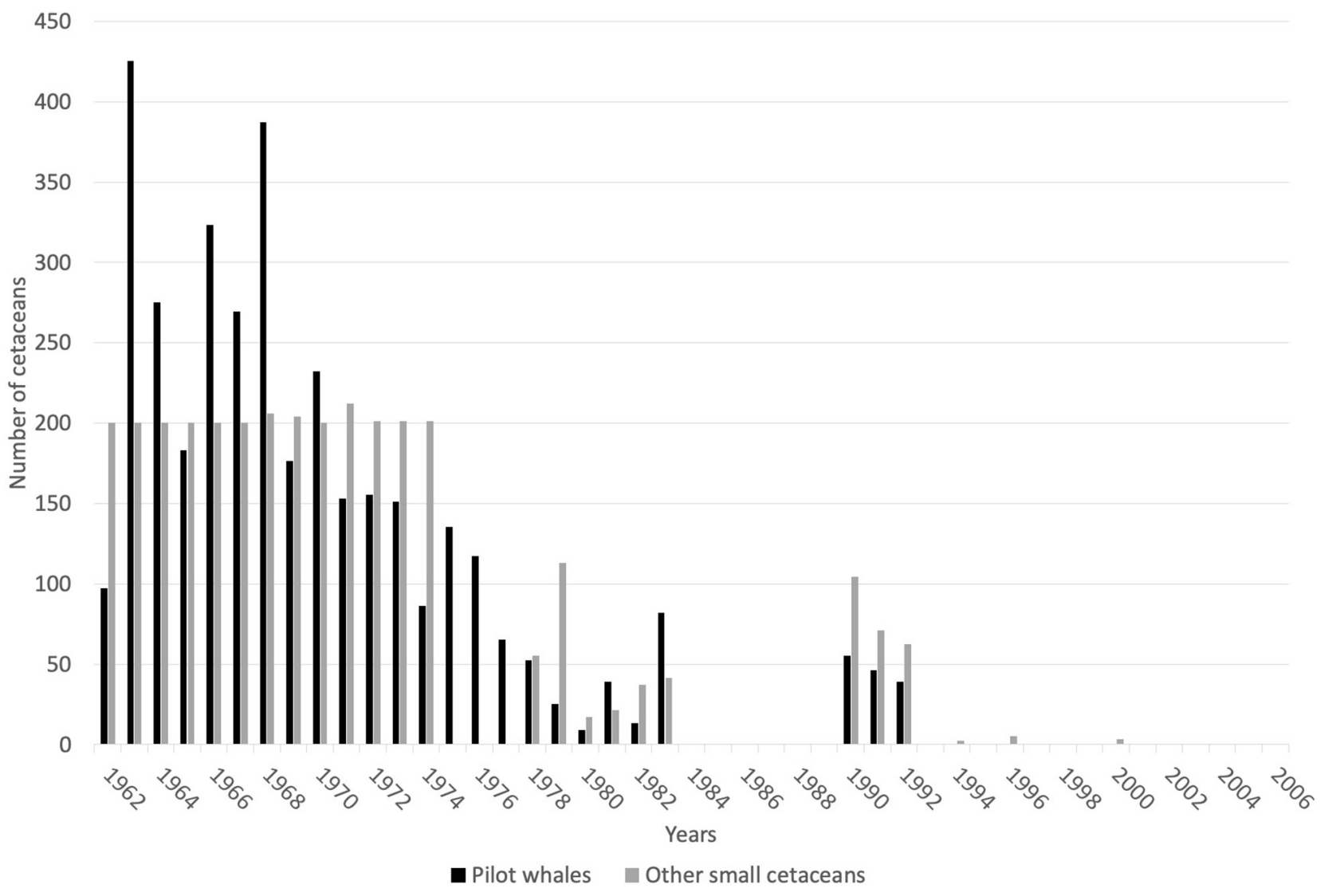

FIGURE 2 | Catch records for small cetaceans taken by whalers based at Barrouallie, St. Vincent, for the period 1962-2006. Gaps represent no data, not zero cetaceans taken. References: Caldwell and Caldwell (1975), Price (1985); Scott (1995), Bolaños-Jiménez et al. (2014).

(within SVG) debate, given the foreign origin of whaling in the region. The small cetacean operation based at Barrouallie could reasonably be considered artisanal whaling, if such a category were to be formalized.

\section{CETACEAN CATCHES IN ST. VINCENT AND THE GRENADINES (1962-2017)}

\section{Small Cetacean Catch Records Prior to 2007}

Records of small cetacean captures are available in the literature from 1949 (but primarily starting in 1962) to 2006, and have been documented in a small number of published sources (Caldwell and Caldwell, 1975; Price, 1985; Scott, 1995; BolañosJiménez et al., 2014). Records are mostly available for three species/species groups: short-finned pilot whales, killer whales, and other cetaceans (primarily delphinids and occasionally other odontocetes). Overall, cetacean catch composition is poorly described but includes at least 11 species (possibly 12), including the short-finned pilot whale, the killer whale, at least one Ziphiidae (Ziphius cavirostris), one Kogiidae, possibly two (Kogia sima identified, but possible captures of $K$. breviceps in
1973; Caldwell and Caldwell, 1975), and at least seven other Delphinidae (Stenella longirostris, S. frontalis, Steno bredanensis, Tursiops truncatus, Grampus griseus, Feresa attenuata, and Pseudorca crassidens; Caldwell and Caldwell, 1971; Caldwell et al., 1973; Caldwell and Caldwell, 1975; Table 1). Species composition provided in the literature is not supported by photographs, and therefore it is important to remain cautious about the occurrence of certain species, particularly those that are relatively difficult to identify (e.g., Feresa attenuata vs. Peponocephala electra). Catch records for most species are limited, and the only available numbers refer to the three species/species group described above. From 1949 to 2006, a total of 10,348 small cetacean captures have been recorded, including 5,130 short-finned pilot whales, 80 killer whales, and 5,588 other small cetaceans. Gaps in data exist for the years 1950-1961, 1984-1989, and 1993-2006. The temporal variation of the annual number of captures is provided in Figure 2 (1962-2006). Numbers of other small cetaceans (i.e., species other than short-finned pilot whales) reported by Caldwell and Caldwell (1975) between 1962 and 1974 is atypically constant (200 individuals per year, Figure 2), and we suspect this number to be an estimate (but no details on how this estimate was made is available). According to the whalers and other local stakeholders, there has not been a year without small cetacean captures in the archipelago in recent decades, 
although the operation did see its lowest annual take in 1980 with only 9 short-finned pilot whales (Adams, 1994; Scott, 1995; Fielding, 2018).

Considering only years for which catch data are available during the period 1962-2006, the average number of reported pilot whale captures per year was 143.2 individuals $(S D=114.45$, min. $=9$, $\max .=425)$. During the same time period, the average number of killer whales caught per year was 3.8 individuals $(S D=3.36$, $\min .=1, \max .=12)$, and the average number of other odontocetes caught per year was 141.7 individuals $(S D=74.7$, $\min .=17, \max .=200)$. Due to gaps in data during the 1962-2006 period and the nature of data for some years (e.g., the estimate of 200 "other dolphin" captures each year from 1962 to 1974 in Caldwell and Caldwell, 1975), we did not investigate inter-annual trends in catch numbers.

\section{Small Cetacean Catch Records From 2007 to 2017}

From 2007 to 2017 (excluding 2013 and 2014), records of a single whaler include 3,058 odontocetes, comprising 766 short-finned pilot whales, 29 killer whales, and 2,263 other small cetaceans (Table 2). During this period, the number of whalers actively engaged in whaling, either part-time or full-time, varied from year to year. Because only one whaler kept reliable records, however, the numbers we present here undoubtedly represent an underestimate for the overall take of the operation. The annual number of days spent at sea whaling by the whaler that we monitored varied between 136 (2011) and 247 days (2007), with a mean of 216.2 days per year during the study period $(S D=32.7)$. Catch rates (number of captures per day spent at sea whaling) of cetaceans varied considerably during the study period and ranged from 0.90 to 3.8 small cetaceans taken per day (Table 2). Species composition was not quantified (except for G. macrorhynchus and O. orca), but several additional species of small odontocetes were recorded during that time period based on field data collection during the Fall 2009, including the Fraser's dolphin (Lagenodelphis hosei), the pantropical spotted dolphin (Stenella attenuata), the Clymene dolphin (Stenella clymene) and the melon-headed whale (Peponocephala electra, Table 1 and Figure 3). Species identifications were all confirmed through the collection of photographs.

Between 2007 and 2017, annual captures of small cetaceans varied between 203 and 927 individuals (all species combined), including 37-203 short-finned pilot whales ( mean $=85.1$, $S D=48.2)$, 0 to 11 killer whales $($ mean $=3.2, S D=3.5)$, and $125-$ 724 other small cetaceans (mean $=251.4, S D=185.7$; Figure 4 and Table 2). Based on whalers' statements, the most commonly caught species under the category "other small cetaceans" were S. attenuata, Lagenodelphis hosei, and S. longirostris. The full species catch composition remains unknown, however, though several new species have been added to the previously known composition of small cetacean captures (Caldwell and Caldwell, 1971, 1975; Caldwell et al., 1971, 1976; Caldwell, 1972), as highlighted above with the addition of at least four species of delphinids that have not been documented prior to 2007. Catch rates for all cetaceans are not following any inter-annual trend (simple linear regressions, all $p>0.05$ ). Although catch rates of pilot whales, killer whales, and other cetaceans did not vary significantly over time, all interviewed whalers have perceived a declining occurrence of pilot whales, and an increasing need to catch other small cetaceans. Future research will be required to investigate temporal trends in small cetacean captures.

\section{Large Whale Catch Records and Estimates Prior to 1986}

Between the end of American whaling in the Caribbean, in 1921, and the beginning of IWC-sanctioned aboriginal subsistence whaling in Bequia in 1987, little is known about the magnitude of the catch of humpback whales and other large whales in the region. In their analysis of nineteenth century whaling logbooks, Reeves et al. (2001) found evidence for the take of 102 humpback whales in the waters surrounding SVG between 1823 and 1889. Adams (1975) and Price (1985) separately analyzed archives that recorded quantities of whale oil exported from SVG to estimate the number of humpback whales that would have been taken during the colonial era. Price (1985) summarizes this research, including the assumptions made, and estimates 509 humpback whales taken between 1898 and 1938. Nearly a half-century elapses between the end of the data analyzed in these archival studies and the commencement of IWC-required monitoring and reporting of humpback takes. During this interim, the best records for humpback takes are from Price (1985) who recorded 54 humpback whales that the whalers reported having killed between 1958 and 1984. Of these, 7 were male, 25 were female, and 22 were calves. Ten were struck-and-lost, mainly females. Additional anecdotal and sporadic accounts of humpback takes are reported in the non-peer-reviewed literature (e.g., AWI, 2012) but consistent, reliable records are absent.

\section{Large Whale Catch Records From 1986 to 2017}

From 1986 to 2020, a total of 47 large whales (Balaenopteridae) captures have been recorded, including 45 humpback whales and 2 Bryde's whales (Balaenoptera edeni, Figure 5). Historically, other species of large cetaceans were caught off SVG, particularly the sperm whale. Records of sperm whale captures are only available from 1958 to 1984, during which time 12 individuals were taken (Caldwell and Caldwell, 1975; Adams, 1985; Price, 1985). No sperm whale captures have been recorded after 1982 .

\section{WHALING METHODS}

Whaling in SVG is a shore-based activity, meaning that there are no large "mother ships" as were used historically by foreign whalers in the Caribbean, nor does the activity last longer at sea than the daylight hours of a single day except in the case of emergencies during inclement weather (Fielding, 2018). Processing takes place either the same day as whaling occurs, or a day or more later, especially if whalers return with their catch late in the day. Methods used in the Barrouallie-based operation have been described by Rack (1952), 
TABLE 2 | Small cetacean captures and catch rates (daily catch rates) by a single whaler off St. Vincent between 2007 and 2017 (except 2013 and 2014 ).

\begin{tabular}{|c|c|c|c|c|c|c|c|c|c|}
\hline \multirow[b]{2}{*}{ Year } & \multicolumn{5}{|c|}{ Numbers } & \multicolumn{4}{|c|}{ Daily catch rates } \\
\hline & $\begin{array}{c}\text { Days spent } \\
\text { whaling }\end{array}$ & $\begin{array}{c}\text { Pilot } \\
\text { whales }\end{array}$ & $\begin{array}{c}\text { Killer } \\
\text { whales }\end{array}$ & $\begin{array}{l}\text { Other small } \\
\text { cetaceans }\end{array}$ & $\begin{array}{c}\text { All } \\
\text { cetaceans }\end{array}$ & $\begin{array}{c}\text { Pilot } \\
\text { whales }\end{array}$ & $\begin{array}{c}\text { Killer } \\
\text { whales }\end{array}$ & $\begin{array}{l}\text { Other small } \\
\text { cetaceans }\end{array}$ & $\begin{array}{c}\text { All } \\
\text { cetaceans }\end{array}$ \\
\hline 2007 & 247 & 64 & 1 & 288 & 353 & 0.259 & 0.004 & 1.166 & 1.429 \\
\hline 2008 & 205 & 84 & 11 & 182 & 277 & 0.410 & 0.054 & 0.888 & 1.351 \\
\hline 2009 & 241 & 203 & 0 & 724 & 927 & 0.842 & 0.000 & 3.004 & 3.846 \\
\hline 2010 & 217 & 37 & 0 & 242 & 279 & 0.171 & 0.000 & 1.115 & 1.286 \\
\hline 2011 & 136 & 66 & 2 & 138 & 206 & 0.485 & 0.015 & 1.015 & 1.515 \\
\hline 2012 & 224 & 100 & 2 & 248 & 350 & 0.446 & 0.009 & 1.107 & 1.563 \\
\hline 2013 & No data & No data & No data & No data & No data & No data & No data & No data & No data \\
\hline 2014 & No data & No data & No data & No data & No data & No data & No data & No data & No data \\
\hline 2015 & 234 & 51 & 4 & 156 & 211 & 0.218 & 0.017 & 0.667 & 0.902 \\
\hline 2016 & 207 & 89 & 3 & 160 & 252 & 0.428 & 0.014 & 0.773 & 1.215 \\
\hline 2017 & 214 & 72 & 6 & 125 & 203 & 0.336 & 0.028 & 0.584 & 0.949 \\
\hline
\end{tabular}

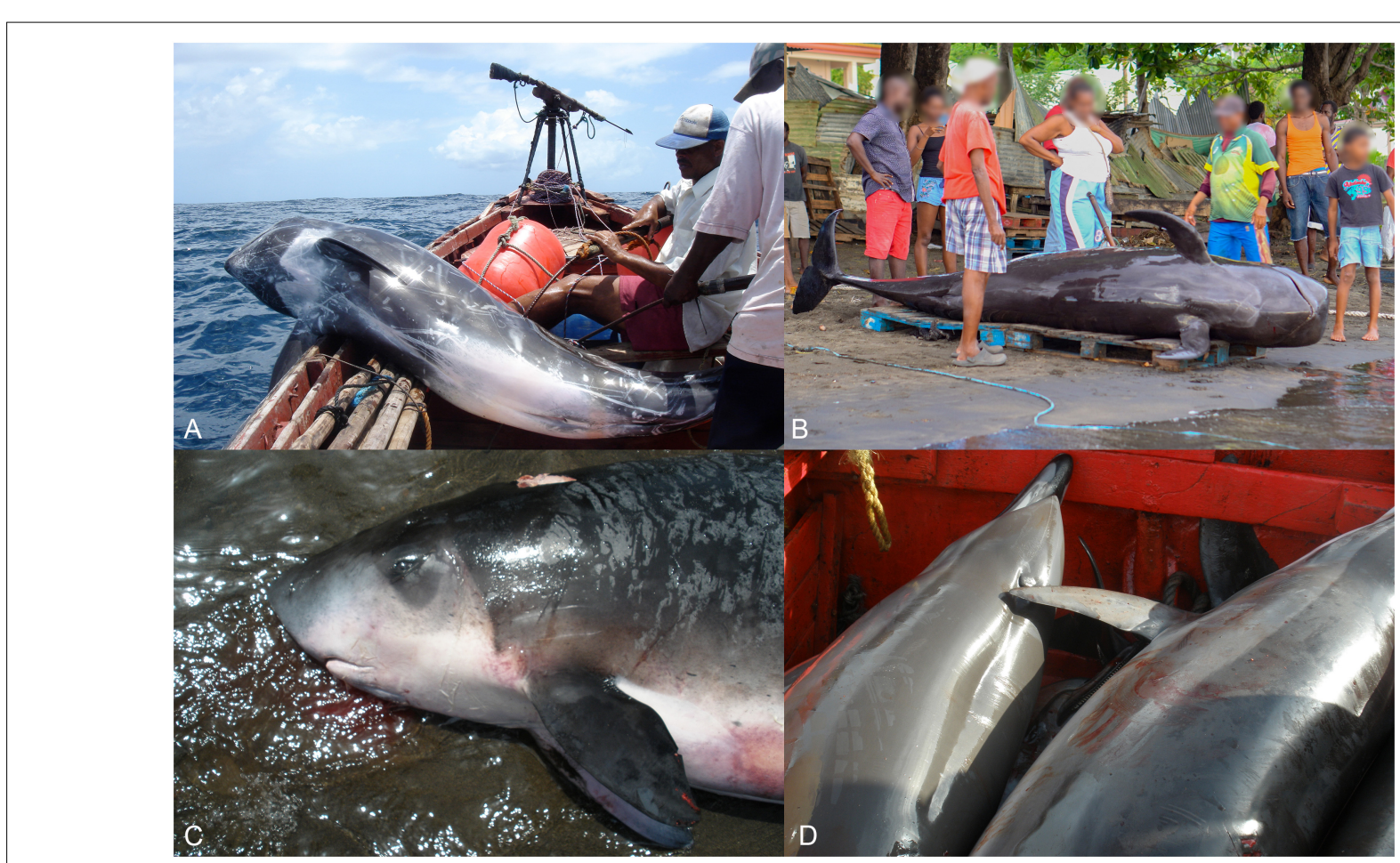

FIGURE 3 | Small cetacean captures in St. Vincent, illustrating the diversity of species caught. (A) Risso's dolphin (Grampus griseus), (B) short-finned pilot whale (Globicephala macrorhynchus), (C) dwarf sperm whale (Kogia sima), and (D) Clymene's dolphins (Stenella clymene). Photographs (A,C,D) by Russell Fielding; Photograph (B) by Adam Gravel.

Caldwell and Caldwell (1971, 1975), Adams (1973), Scott (1995), Hamaguchi (2002), and Fielding (2018). Additional ethnographic insight is provided by the analysis of whaling-related shanties by Abrahams (1974) and Lanier and Reid (2007).

Whaling voyages for small cetaceans commence from Barrouallie most mornings except Sundays. A voyage begins with a loosely defined transect in search of small cetaceans to leeward (west) of Barrouallie, or, if conditions allow, in the St. Vincent Passage, the channel separating St. Vincent from St. Lucia to the north. Three crewmembers are usually part of whaling trips: the harpooner/captain, the sternman, and the centerman. All contribute to the watch and follow environmental clues such as flocks of diving seabirds, or dorsal fins, flukes, and "blows" visible just above the water's surface to locate cetaceans. In more recent years, however, whalers have begun to navigate directly toward one or more of the fish aggregating devices (FADs) placed off the coast since they believe FADs attract several species of odontocetes, including short-finned pilot whales. In addition, in recent years, the increasing presence of sargassum floats (Sargassum spp., e.g., van Tussenbroek et al., 2017) off St. Vincent 
800

700

600

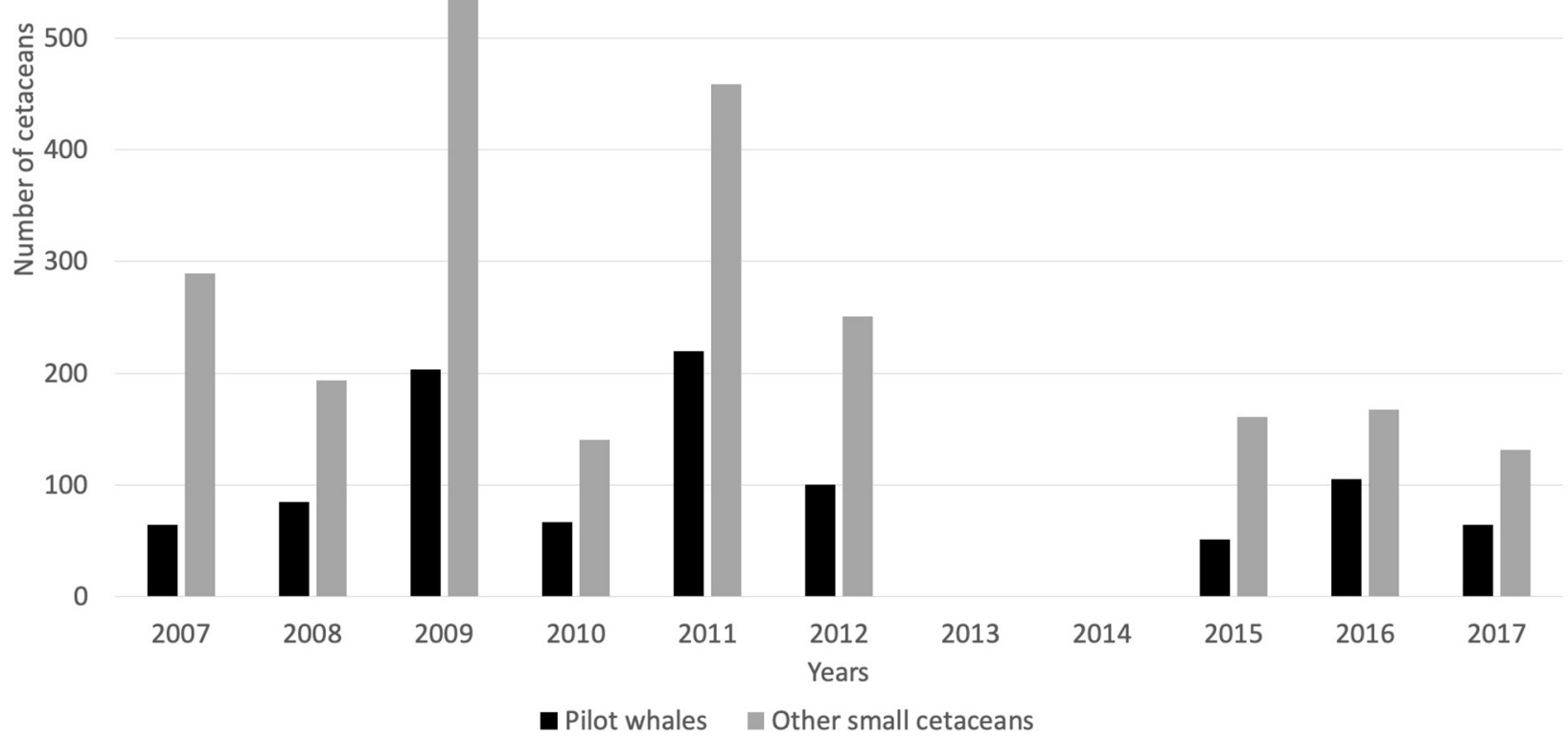

FIGURE 4 | Catch records for small cetaceans taken by a single whaling boat from 2007 to 2017 (no data available in 2013 and 2014).

has slightly affected whaling practices. Some whalers believe there is an increasing use of these floats by large pelagic fishes (particularly mahi-mahi Coryphaena hippurus), and therefore by several cetacean species, particularly false killer whales.

When a small cetacean is within range, a whaler either fires a meter-long harpoon from a modified shotgun mounted on the boat's bow or throws a two-meter-long harpoon by hand, typically aiming for a spot just behind the dorsal fin (Figure 6). The harpoon's toggling head embeds in the cetacean, which is then hauled close to the boat by hand. Larger delphinids such as pilot whales and killer whales are lashed alongside the boat; individuals of smaller species are hauled over the gunwales and kept inside (Figure 6). Fielding (2010) found that the average time-to-death in the Barrouallie-based operation targeting small cetaceans was approximately $9 \mathrm{~min}$. This figure was based on the direct observation and timing of the captures of twenty-two small cetaceans (17 Stenella longirostris and 5 S. frontalis).

When the harpooner, who acts as captain, determines that whaling for the day is complete, the boat returns to Barrouallie to sell its catch. Barrouallie-based vendors purchase small cetaceans wholesale and process the carcasses on the beach for retail sale. Muscle tissue is dried to produce a jerky-like meat, which is later rehydrated for cooking, and blubber is cooked over fire to produce "crisps," a popular snack consisting of small cubes of fried blubber, often with the skin still attached, and oil, used as a folk remedy for colds and for other household purposes (Figure 7).

Bequia-based whaling has been described frequently in both the scientific literature and popular press. The earliest first-hand account we analyzed is that of Fenger (1917), who visited the Grenadines in 1911 and accompanied a whaling voyage from Île-de-Caille, Grenada. At Bequia, Fenger met with William Wallace, who is regarded as the first local whaler in the Grenadines (Fenger employs Homeric imagery in calling Wallace "the Nestor of whalemen in the Grenadines"). Because whaling throughout the Grenadines developed according to Wallace's model, established in Bequia, we take Fenger's description of Grenadian whaling to apply to contemporaneous Bequian whaling in the early twentieth century as well. Other notable scholarly sources of description come from Adams (1971, 1994), Balcomb (1981); Delves (1981), Ward (1987, 1995), Beck (1987), and Hamaguchi (2001, 2005). Additional insights are furnished by Finneran's archeological study Finneran's (2016). Popular descriptive accounts include Junger (2001), Weston (2014), and Palmer (2017).

Bequian whalers typically put to sea only after a humpback whale has been sighted; sightings usually occur from shore but are occasionally made by someone aboard a non-whaling vessel. Sailboats are used to first approach and harpoon the whale but motorized boats often supplement the effort and are used as 
4

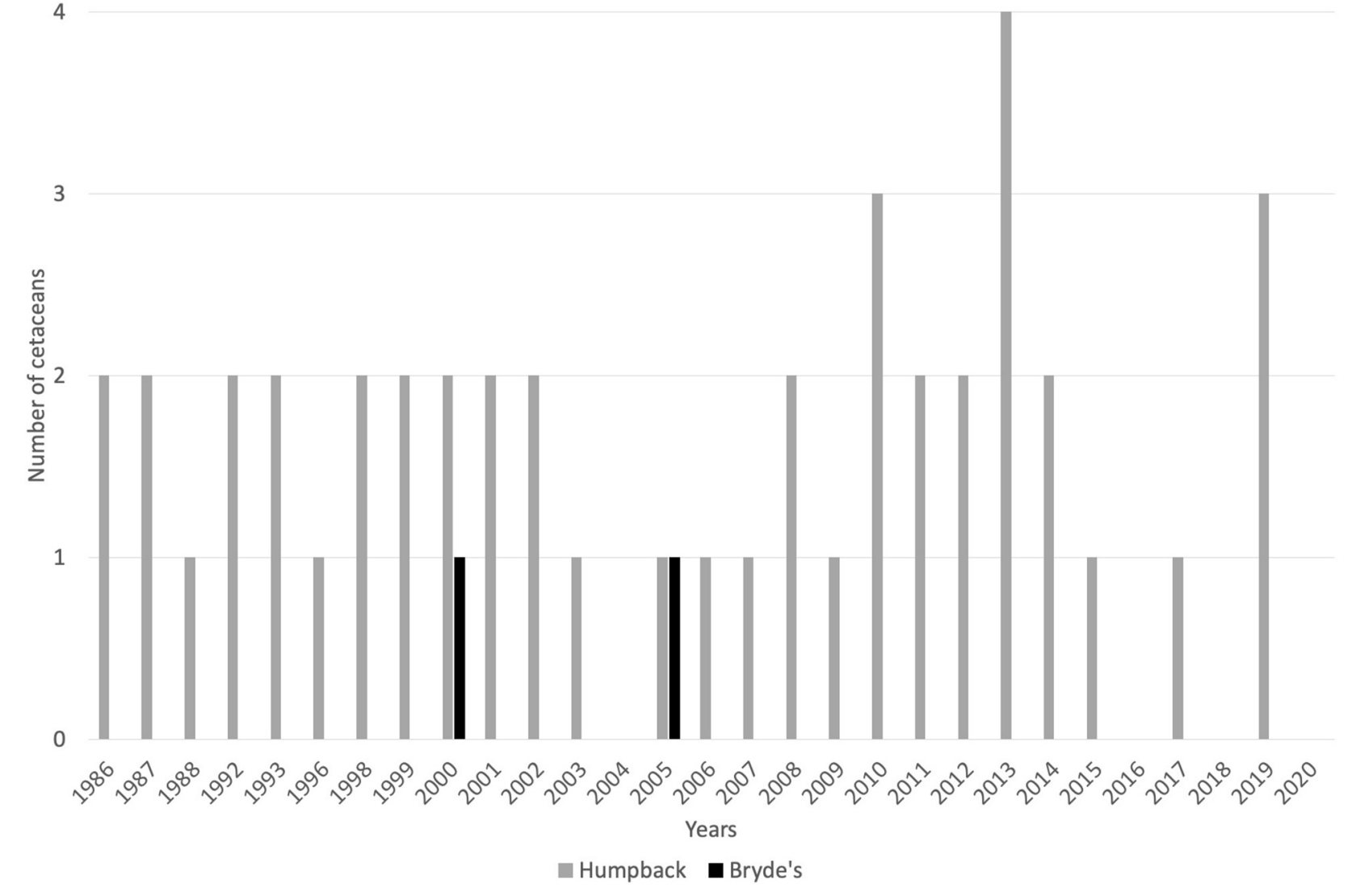

FIGURE 5 | Catch records for IWC-protected whales taken by whalers based at Bequia and Barrouallie, SVG, for the period 1986-2020. Gaps represent zero cetaceans taken. Source: IWC (2021). Not included is the occasional, unreported take of sperm whales by Barrouallie-based whalers.

the primary vessels for towing the whale to shore. Six whalers crew the boat: a harpooner, the captain/steerer, and four seamen. Harpoons are hand-thrown; the gun is not used in Bequia whaling. When a whale has been struck, the harpooner lances it repeatedly to hasten its death. A bomb lance may also be used. Humpback whales are brought ashore to the whaling station at Semple Cay, an islet off the south coast of Bequia, for processing.

\section{MANAGEMENT OF WHALING ACTIVITIES}

Whaling operations in SVG are managed by the Fisheries Division of the government's Ministry of Agriculture, Forestry, Fisheries, Rural Transformation, Industry, and Labour. Owing to the IWC oversight, the Bequia-based operation targeting humpback whales is considerably more heavily regulated than the Barrouallie-based small cetacean operation. The SVG government has established its domestic whaling policy in accordance with its obligations as host to an aboriginal subsistence whaling under the rules of the International Whaling Commission (SVG, 2003). The IWC currently allows a maximum of four humpback whales per year to be taken by Bequiabased whalers. Technically, the limit is set at 28 whales during the 7-year period spanning 2019-2025, which works out to four per year but, based upon the wording of the quota, could potentially result in more than four whales taken in some years if fewer are taken in others (IWC, 2018). It has been repeatedly shown that the Bequia-based whaling operation has violated Article 14 of the IWC schedule that prohibits "suckling calves or females accompanied by calves to be taken.” Ample photographic evidence clearly shows that females with calves have been taken, which prompted considerable discussion and controversy at the Scientific Committee of the IWC (Clapham et al., 1999). Additionally, cases of "struckand-lost" humpback whales occur with such regularity in the Bequia operation as to call into question the efficacy of the whaling methods employed there. For example, Price (1985) indicates that during the period from 1958 to 1984,10 of the 54 humpback whales killed were lost before landing. By contrast, intensive observations of Barrouallie-based whaling for small cetaceans revealed no similar prevalence of the preferential targeting of calves or of struck-and-lost small cetaceans (Fielding, 2018).

The Barrouallie-based operation targeting small cetaceans is only loosely monitored by the Fisheries Division of the Ministry of Agriculture, Forestry, Fisheries, Rural Transformation, Industry, and Labour; its regulation largely falls to the traditional 


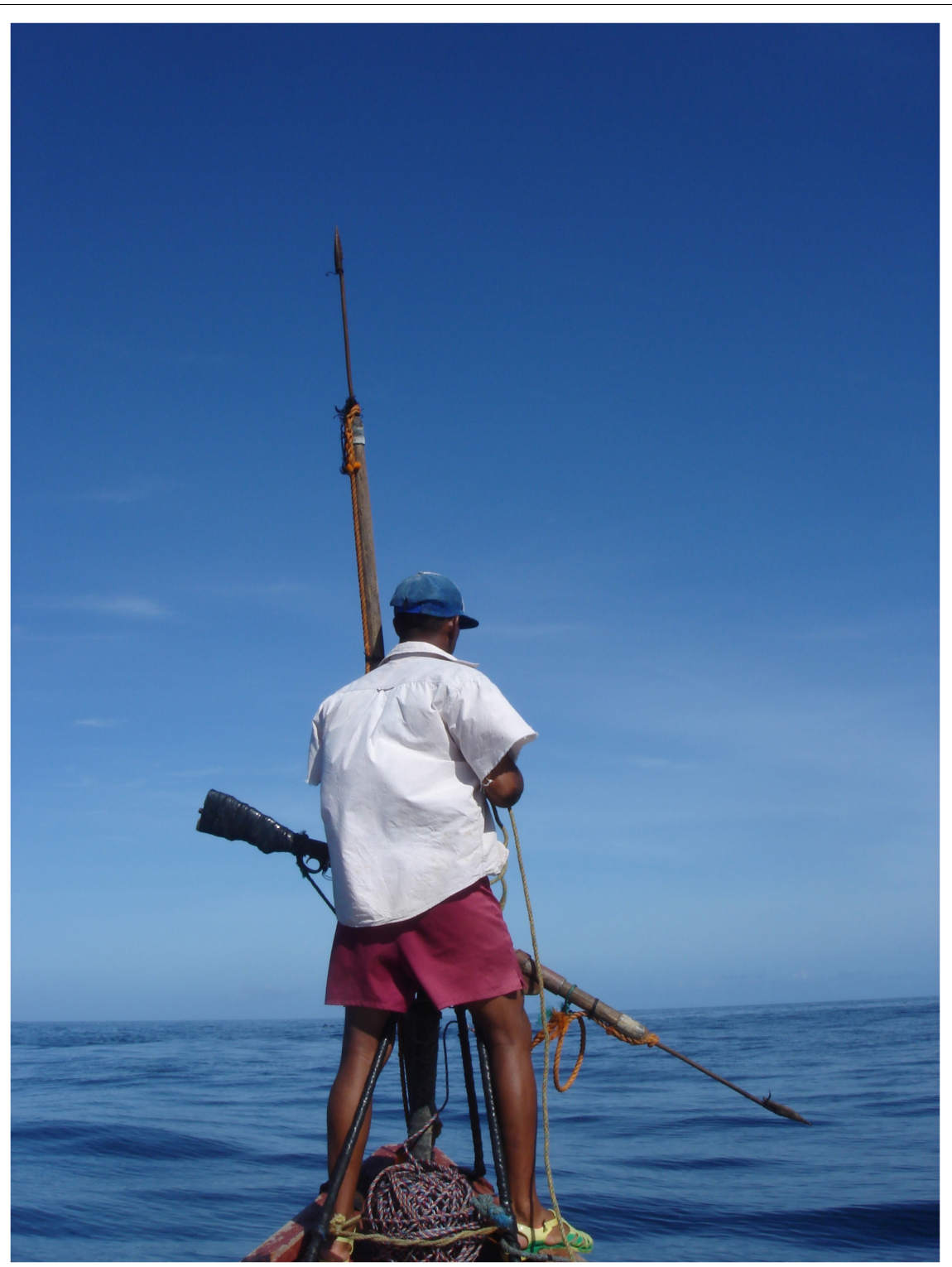

FIGURE 6 | A Barrouallie-based whaler standing in the bow of a whaling boat. Visible are both types of harpoons used: the two-meter long hand-thrown harpoon, which the whaler holds nearly vertical in this image, and the meter-long gun-fired harpoon, which points downward and is loaded in the gun mounted at the bow. Photograph by Russell Fielding.

management schemes that have been referred to as "culturally embedded conservation strategies" (Fielding, 2018). Culturally embedded conservation strategies include social practices, organizational structures, and perceived limitations on activity or technology that collectively serve to restrain the exploitation of a natural resource, even in the absence of formal environmental policy. They are most effective in societies with "relatively constant group membership, long-term residence in an area, and heavy reliance on natural resources" (Jones et al., 2008). Previous research in other geographical contexts has identified similar practices using terms such as "customary environmental law" (Zerner, 1994), "customary resource management norms" (Fernandez-Gimenez et al., 2008), “indigenous wildlife resource management" (Ipara, 2005), "resource and habitat taboos" (Colding and Folke, 2001), "ritual regulation" (Rappaport, 1967), or "traditional conservation methods" (Johannes, 1978). We prefer the term "culturally embedded conservation strategies" because it simultaneously acknowledges both the hiddenness and the strategic nature of the conservation system, while distancing itself from loaded concepts such as "ritual" or "taboo."

In SVG, these strategies include the geographical restriction of whaling activities targeting small cetaceans to boats and crews based in Barrouallie, to the exclusion of other villages, and whalers' general resistance to the adoption of new technologies that might increase their efficiency. Adherence to these 


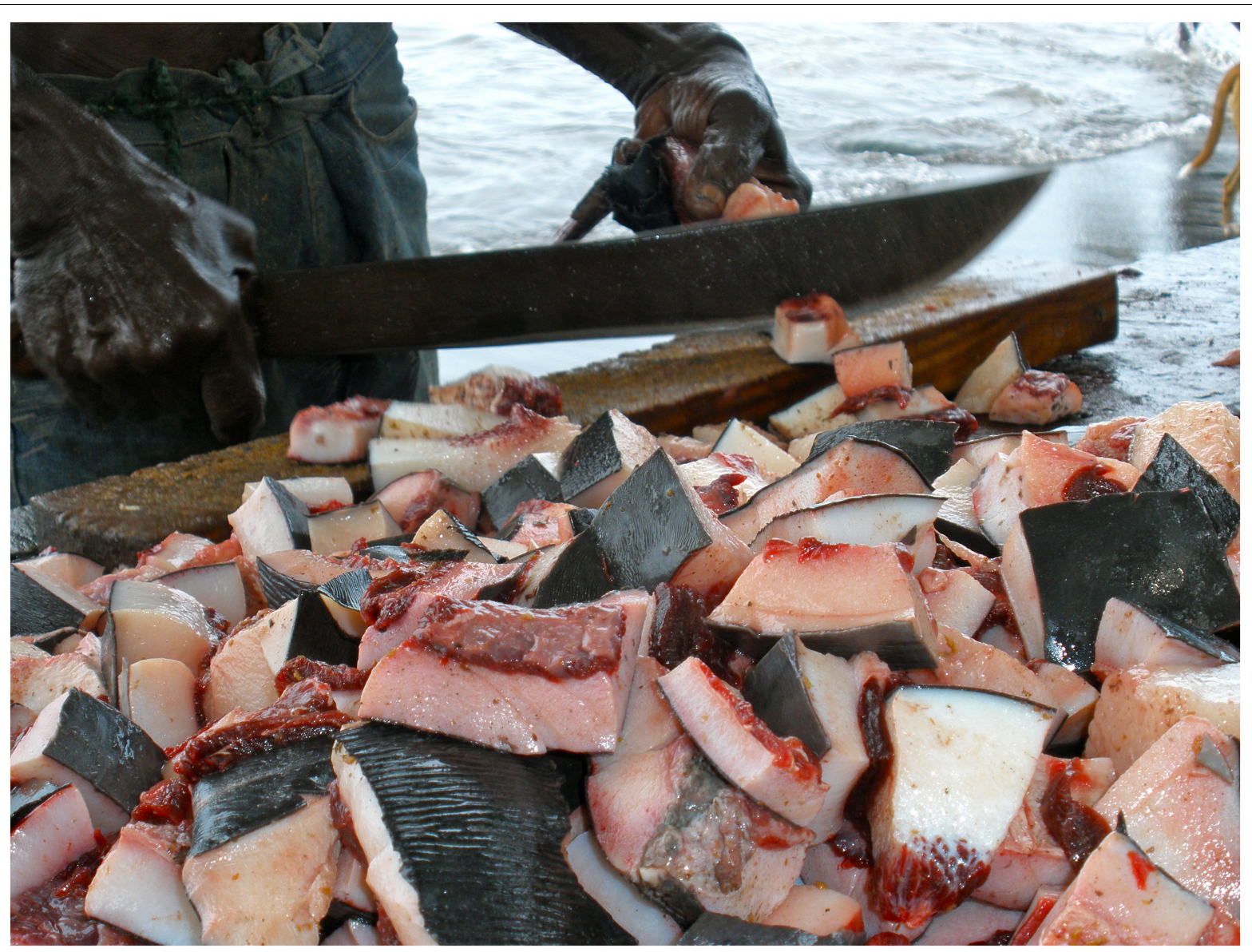

FIGURE 7 | Blubber from an unidentified small cetacean being prepared as "crisps" on the beach at Barrouallie. Photograph by Russell Fielding.

culturally embedded conservation strategies may limit the take of small cetaceans, compared to what it would be in their absence. No quota exists for small cetaceans taken in SVG, although there is some evidence that whalers reduce their effort when recent catches have been large, supply of whale meat and other products is high, and retail prices are in danger of falling (Fielding, 2018). Owing to their culturalembeddedness, adherence to these conservation strategies can often be remarkably consistent. Fernandez-Gimenez et al. (2008) quote an Alaskan whaler as saying, "The unwritten laws are written in our hearts." When culturally embedded conservation strategies stand in for formal conservation policy that is either absent or inadequate, the informal policies can be effective means of managing natural resources in certain contexts characterized by cultural homogeneity and community-based resource exploitation. Whether culturally embedded conservation strategies are sufficient to maintain sustainable levels of small cetacean exploitation in SVG, however, is unknown. To determine the sustainability of the operation in general, and the effectiveness of the conservation strategies specifically, more information is needed regarding the abundance, movements, and population structure of small cetaceans in the Caribbean.
Both SVG-based whaling operations are internationally controversial. Much of the opposition to the Bequia operation centers upon the problematic definition of "aboriginal" in the context of Caribbean whaling (Fielding, 2017). Indeed, the placement within quotes of the word "aboriginal" when used in reference to Caribbean whaling is common in conservationfocused literature (e.g., Spong, 2007; AWI, 2012; Watson, 2012; Marine Connection, 2019). The legitimacy of designating the Bequia operation as aboriginal subsistence whaling was further called into question in 2012 as Louise Mitchell, a Bequia-born attorney speaking on behalf of the Eastern Caribbean Coalition of Environmental Awareness, a regional conservation NGO, delivered remarks at a meeting of the IWC that emphasized the lack of pre-European whaling by Caribbean people, the American origins of present-day Caribbean whaling, and the "mixed European and African descent" of the individuals engaged in whaling from Bequia (ECCEA, 2012). Fielding (2017) has offered critique of the centralization of whalers' ethnicity in discussions of aboriginal subsistence whaling, but its centrality in current definitions of "aboriginal" (e.g., Anaya, 1996) tends to inhibit progress beyond an ethnicity-focused discussion. While some environmental literature has begun to explore the possibility of "becoming indigenous to [a] 
place" (Kimmerer, 2013, p. 205; see also Sakakibara, 2020 for a whaling-specific discussion of the concept), the dominant view remains that one either is or is not born indigenous, therefore aboriginal.

Opposition to the Barrouallie-based operation targeting small cetaceans has been far less widespread than that directed at Bequia. Fielding (2018) speculates that both the relative obscurity of the Barrouallie operation and the perception of need may play roles in the lack of anti-whaling efforts directed there.

\section{EMERGING ISSUES AND RECOMMENDATIONS FOR FUTURE RESEARCH}

Both SVG-based whaling operations face multiple emerging social and environmental issues. These include the pressing need to determine the impacts of both whaling operations on their target species. Although a number of species are currently listed as "Least Concern" or "Data Deficient" on the IUCN Red List, the regional status of most cetaceans taken in SVG is unknown. Catches of several hundred individuals of certain species per year, particularly short-finned pilot whales, may present a risk for populations occurring in the Caribbean region. For other species that are known to be relatively rare in the region and that have low reproductive rates (e.g., the killer whale; Bolaños-Jiménez et al., 2014), current catch levels might also have a significant impact. Therefore, research is critically needed to assess the impact of small cetacean captures on these populations, which has previously not been carried out in SVG. The abundance of all cetaceans taken in SVG whaling operations is unknown. However, whalers seem to perceive a decline of some species, particularly shortfinned pilot whales, the main target species in Barroualliebased operations. Although this decline is not documented with appropriate data, the perceived decreasing abundance of pilot whales should be urgently investigated. Overall, the sustainability of small cetacean exploitation in SVG needs to be assessed through a systematic collection and investigation of catch records, and the assessment of the abundance of the most targeted species. The identification of proper methods to assess absolute abundance of small cetaceans (e.g., using line-transect and/or photo-identification methods) should be carried out, and implemented locally based on local and international resources and capacity. In addition, investigating small cetacean population structure is critical, particularly to identify population boundaries and management units at the scale of the Caribbean region. Various approaches and methods should be used across multiple spatial and temporal scales, from genetic analysis of population structures to the tracking of individual cetacean movements using satellite tagging, for example.

Recent studies have found elevated levels of mercury in tissues sampled from small cetaceans taken by SVG-based whalers, and most tissues used for food exceeded the FAO and the World Health Organization human consumption advisory level of $1.0 \mu \mathrm{g} / \mathrm{g}$ wet weight (McCormack et al., 2020). The health implications of mercury intake are significant, but poorly understood. Additional recent studies have shown that the vast majority $(77.4 \%)$ of the SVG population consumes cetaceanbased food products, often in excess of safe weekly limits (Fielding et al., 2021). Investigating the health effects of cetacean products is critical from a public health perspective.

In 2017, conflict arose between whalers and whale-watching tour operators off the coast of Barrouallie (Fielding, 2018). Two killer whales were harpooned within sight of a whale-watching boat, an event that led to some of the most vocal opposition that the Barrouallie operation had ever seen (e.g., Gibbens, 2017; Wootson, 2017). Similar, but less intense conflicts have occurred with regard to the Bequia-based operation. As tourism resumes in the region after the COVID-19 pandemic, future negative interactions between the tourism and whaling sectors are likely. Domestic and foreign environmental organizations have recently funded the establishment of additional whalewatching operations to be based in Bequia and Barrouallie (Groves, 2019; SVGEF, 2019). The proximity of these operations to the established whaling operations may increase the risk of conflicts. Finally, the public perception of whaling, both within SVG and internationally, continues to evolve. As in any economic system, whaling is dependent upon the demand for the goods it produces. If demand were to reduce, whaling would likely reduce in response.

In the near future, the implementation of research activities should be carried out locally and collaboratively, at the local, regional (Eastern Caribbean), and international levels. Such a multiscale program would ideally involve whalers, cetacean processors and vendors, governmental and non-governmental bodies, and the scientific community. Capacity-building through collaborations between local and international researchers, and the training of local students could contribute to effective monitoring of whaling activities and to the broader sustainability of Caribbean whaling.

\section{AUTHOR CONTRIBUTIONS}

Both authors listed have made a substantial, direct and intellectual contribution to the work, and approved it for publication.

\section{ACKNOWLEDGMENTS}

This work would not have been possible without the help of long-term collaborators in Saint Vincent and the Grenadines, including Vincent Reid, Samuel Hazelwood, Chief Fisheries Officer Jennifer Cruickshank-Howard, Fisheries Officer Chris Isaacs, and the Honourable Saboto Caesar, Minister of Agriculture, Forestry, Fisheries, Rural Transformation, Industry and Labour. We also thank Haley Tucker (University of the South) for her painstaking transcription of the handwritten 2007-2017 catch records. This is contribution \#250 of the Coastal and Oceans Division in the Institute of Environment at Florida International University. 


\section{REFERENCES}

Abrahams, R. D. (1974). Deep the Water, Shallow the Shore: Three Essays on Shantying in the West Indies. Austin, TX: University of Texas Press.

Acosta, J. (2002). Natural and Moral History of the Indies. Durham, NC: Duke University Press.

Adams, J. E. (1971). Historical Geography of Whaling in Bequia Island, West Indies. Carib. Stud. 11, 55-74. doi: 10.1201/9781420039481.ch4

Adams, J. E. (1973). Shore Whaling in St. Vincent, West Indies. Caribb. Q. 19, 42-50. doi: 10.1080/00086495.1973.11829171

Adams, J. E. (1975). Primitive Whaling in the West Indies. Sea Front. 21, 303-313.

Adams, J. E. (1985). The Fisheries and Fish Markets of St. Vincent Island, Eastern Caribbean, Singap. J. Trop. Geogr. 6, 1-12. doi: 10.1111/j.1467-9493.1985. tb00156.x

Adams, J. E. (1994). Last of the Caribbean Whalemen. J. Nat. Hist. 103, 64-72.

Anaya, S. J. (1996). Indigenous Peoples in International Law. New York, NY: Oxford University Press.

Animal Welfare Institute [AWI], (2012). Humpback Whaling in Bequia, Saint Vincent and the Grenadines: The IWC's Failed Responsibility. Washington, DC: AWI.

Archer, A. S. (1881). Sea-Fishing in Barbadoes. Field 1054:592.

Balcomb, K. (1981). Whale Reports from Bequia, St. Vincent Grenadines. Cetus 3, 4-6.

Barragán-Barrera, D. C., Do Amaral, K. B., Chávez-Carreño, P. A., Farías-Curtidor, N., Lancheros-Neva, R., Botero-Acosta, N., et al. (2019). Ecological niche modeling of three species of Stenella dolphins in the Caribbean Basin, with application to the Seaflower Biosphere Reserve. Front. Mar. Sci. 6:10. doi: 10. 3389/fmars.2019.00010

Beck, H. P. (1987). Bleows, The Whaling Complex of Bequia. Washington, D.C: Folklife Annual, 42-61.

Bolaños-Jiménez, J., Mignucci-Giannoni, A. A., Blumenthal, J., Bogomolni, A., Casas, J. J., Henríquez, et al. (2014). Distribution, feeding habits and morphology of killer whales Orcinus orca in the Caribbean Sea. Mammal Rev. 44, 177-189. doi: 10.1111/mam.12021

Brandt, K. (1940). Whale Oil: An Economic Analysis. Stanford, CA: Food Research Institute.

Brown, H. H. (1945). The Fisheries of the Windward and Leeward Islands. Devel. Welfare West Ind. Bull. 20, 1-97.

Caldwell, D. K. (1972). Odontocete cetaceans at St. Vincent in the Lesser Antilles. Year Book Am. Philosoph. Soc. 1972, 349-352.

Caldwell, D. K., and Caldwell, M. C. (1971). Porpoise Fisheries in the Southern Caribbean-Present Utilization and Future Potentials. Proc. Gulf Caribb. Fish. Inst. 23, 195-211.

Caldwell, D. K., and Caldwell, M. C. (1975). Dolphin and small whale fisheries of the Caribbean and West Indies: occurrence, history, and catch statistics-with special reference to the Lesser Antillean Island of St. Vincent. J. Fish. Res. Board Can. 32, 1105-1110. doi: 10.1139/f75-132

Caldwell, D. K., Caldwell, M. C., and Arrindell, G. (1973). Dwarf Sperm Whales, Kogia simus, from the Lesser Antillean Island of St. Vincent. J. Mammal. 54, 515-517. doi: 10.2307/1379143

Caldwell, D. K., Caldwell, M. C., Rathjen, W. F., and Sullivan, J. R. (1971). Cetaceans from the Lesser Antillean island of St. Vincent. Fishery Bull. 69, 303-312.

Caldwell, D. K., Caldwell, M. C., and Walker, R. V. (1976). First records for Fraser's dolphin (Lagenodelphis hosei) in the Atlantic and the melonheaded whale (Peponocephala electra) in the western Atlantic. Cetology 25, $1-4$.

Clapham, P., and Van Waerebeek, K. (2007). Bushmeat and bycatch: the sum of the parts. Mole. Ecol. 16, 2607-2609. doi: 10.1111/j.1365-294x.2007.03378.x

Clapham, P. J., Wetmore, S. E., Smith, T. D., and Mead, J. G. (1999). Length at birth and at independence in humpback whales. J. Cetacean Res. Manag. 1, 141-146.

Colding, J., and Folke, C. (2001). Social Taboos: "Invisible" Systems of Local Resource Management and Biological Conservation. Ecol. Appl. 11, 584-600. doi: 10.2307/3060911

Cosentino, A. M., and Fisher, S. (2016). The Utilization of Aquatic Bushmeat from Small Cetaceans and Manatees in South America and West Africa. Front. Mar. Sci. 3:163. doi: 10.3389/fmars.2016.00163

Delves, A. (1981). Whaling in Bequia. Cetus 3, 6-7.
Donovan, G. P. (1982). The international whaling commission and aboriginal/subsistence whaling: April 1979 to July 1981. Rep. int. Whal. Commn. 4, 79-86.

Fenger, F. A. (1917). Alone in the Caribbean. New York: Doran.

Fernandez-Gimenez, M. E., Hays, J. U. Jr., Huntington, H. P., Andrew, R., and Goodwin, W. (2008). Ambivalence toward Formalizing Customary Resource Management Norms among Alaska Native Beluga Whale Hunters and Tohono O’odham Livestock Owners. Hum. Organ. 67, 137-150. doi: 10.17730/humo. 67.2.008083027273n05q

Fielding, R. (2010). Artisanal Whaling in the Atlantic: a Comparative Study of Culture, Conflict, and Conservation in St. Vincent and the Faroe Islands. Ph D. thesis, Louisiana State University: Baton Rouge, LA.

Fielding, R. (2017). "Indigeneity and Ecology in Alaskan and Faroese Whaling," in Critical Norths: Space, Nature, Theory, eds K. Maier, and S. J. Ray, (Fairbanks, AK: University of Alaska Press), 87-102.

Fielding, R. (2018). The Wake of the Whale: Hunter Societies in the Caribbean and North Atlantic. Cambridge, MA: Harvard University Press.

Fielding, R., Kiszka, J., Macdonald, C., McCormack, M. A., Dutton, J., Ollivierre, A., et al. (2021). Demographic and Geographic Patterns of Cetacean-based Food Product Consumption and Potential Mercury Exposure within a Caribbean Whaling Community. Hum. Ecol. Risk Assess 2021, 1-25. doi: 10.1080/ 10807039.2020.1870865

Finneran, N. (2016). Slaves to Sailors: the Archaeology of Traditional Caribbean Shore Whaling, c.1850-2000. A Case Study from Barbados and Bequia (St Vincent Grenadines). Int. J. Naut. Archaeol. 45, 388-405. doi: 10.1111/10959270.12184

Fitzpatrick, S. M., and Keegan, W. F. (2007). Human Impacts and Adaptations in the Caribbean Islands: an Historical Ecology Approach. Earth Environ. Sci. Trans. R. Soc. Edinb. 98, 29-45. doi:10.1017/s1755691007 000096

Fitzpatrick, S. M., Keegan, W. F., and Sealey, K. S. (2008). "Human Impacts on Marine Environments in the West Indies during the Middle to Late Holocene," in Human Impacts on Ancient Marine Ecosystems: A Global Perspective, eds T. C. Rick, and J. Erlandson, (Berkeley, CA: University of California Press), 147-164. doi: 10.1525/9780520934290-009

Gero, S., Gordon, J., Carlson, C., Evans, P., and Whitehead, H. (2007). Population estimate and inter-island movement of sperm whales, Physeter macrocephalus, in the Eastern Caribbean Sea. J. Cetacean Res. Manag. 9, 143-150.

Gero, S., and Whitehead, H. (2016). Critical decline of the Eastern Caribbean sperm whale population. PLoS One 11:e0162019. doi: 10.1371/journal.pone.0162019

Gibbens, S. (2017). Killing of Orcas in Front of Tourists Could Spell End of Whaling for Island Nation. National Geographic. Available online at: https://www.nationalgeographic.com/news/2017/04/orcas-killed-touristsst-vincent-whaling/ [Accessed Feb 16, 2021]

Gillespie, A. (2001). Small Cetaceans, International Law and the International Whaling Commission. Melb. J. Int. Law 2, 257-303.

Gómez, A., Rodríguez, J., Jiménez, N., Cabezas, F., Rodríguez, J. E., and Matamoros, Y. (eds) (2011). "Viabilidad de la Población y el Hábitat del Manatí (Trichechus manatus manatus) en el Caribe.Estrategia para la conservación de la especie. 20-24 de junio, 2011," in Zoológico y Jardín Botánico Nacional Simón Bolivar, (Mesoamérica: UICN/SSC Conservation Breeding Specialist Group).

Groves, D. (2019). Whalers turn whale watchers. Whale and Dolphin Conservation. Available online at: https://us.whales.org/2019/11/22/whalers-turn-whalewatchers/ [accessed on Dec 30, 2020].

Hamaguchi, H. (2001). Bequia Whaling Revisited: To the Memory of the Late Mr. Athneal Ollivierre. Sonoda J. 36, 41-57.

Hamaguchi, H. (2002). A Report on Whaling in Barrouallie, Saint Vincent and the Grenadines. Nihonkai Cetol. 10, 19-22.

Hamaguchi, H. (2005). "Use and Management of Humpback Whales in Bequia, Saint Vincent and the Grenadines," in Indigenous Use and Management of Marine Resources, ed. N. Kishigami, (Osaka: National Museum of Ethnology), 87-100.

Hickling, C. F. (1950). The Fisheries of the British West Indies: Report on a Visit in 1949, Development and Welfare in the West Indies, Bulletin 29. Bridgetown: Cole's Printery.

Ipara, H. (2005). Indigenous Wildlife Resource Management Systems of the Isukha Community of Western Kenya. Hum. Dimens. Wildl. 10, 141-142. doi: 10.1080/ 10871200590931833 
International Whaling Commission [IWC] (2021). Aboriginal Subsistence Whaling Catches Since 1985. Available online at: https://iwc.int/table_aboriginal (accessed March 31, 2021).

IWC [International Whaling Commission], (2018). Annex P: Amendments to the Schedule Adopted at the 67th Meeting. Schaffhausen: IWC.

IWC [International Whaling Commission], (2019). Report of the IWC Scientific Committee Nairobi, Kenya, 10-23 May 2019 SC/68A. Schaffhausen: IWC.

Johannes, R. E. (1978). Traditional Marine Conservation Methods in Oceania and Their Decline. Ann. Rev. Ecol. Sys. 9, 349-364. doi: 10.1146/annurev.es.09. 110178.002025

Jones, J. P. G., Andriamarovololona, M. M., and Hockley, N. (2008). The Importance of Taboos and Social Norms to Conservation in Madagascar. Cons. Bio. 22, 976-986. doi: 10.1111/j.1523-1739.2008.00970.x

Junger, S. (2001). The Whale Hunters," chapter 3 in Fire [Originally published in Outside magazine, October 1995]. New York: Norton.

Kimmerer, R. W. (2013). Braiding Sweetgrass: Indigenous Wisdom, Scientific Knowledge and the Teachings of Plants. Minneapolis, MN: Milkweed.

Lanier, D., and Reid, V. (2007). Whalers' Shanties of Barrouallie, St. Vincent: Observations on the Nature, Decline and Revival of a Unique Caribbean Maritime Tradition. Int. J. Intang. Heritage 2, 70-80.

Le Boeuf, B. J., Kenyon, K. W., and Villa-Ramirez, B. (1986). The Caribbean monk seal is extinct. Mar. Mamm. Sci. 2, 70-72. doi: 10.1111/j.1748-7692.1986. tb00028.x

Marine Connection, (2019). Addressing 'aboriginal' whaling in the Caribbean. Available online at: https://marineconnection.org/addressing-aboriginalwhaling-in-the-caribbean/ [accessed on Nov 30, 2020]

McClenachan, L., and Cooper, A. B. (2008). Extinction rate, historical population structure and ecological role of the Caribbean monk seal. P. Roy. Soc. B Biol. Sci. 275, 1351-1358. doi: 10.1098/rspb.2007.1757

McCormack, M. A., Fielding, R., Kiszka, J. J., Paz, V., Jackson, B. P., Bergfelt, D. R., et al. (2020). Mercury and selenium concentrations, and selenium:mercury molar ratios, in small cetaceans taken off St. Vincent, West Indies. Env. Res. 181:108908. doi: 10.1016/j.envres.2019.108908

McKillop, H. (1985). Prehistoric exploitation of the manatee in the Maya and circum-Caribbean areas. World Archaeol. 16, 337-353. doi: 10.1080/00438243. 1985.9979939

Palmer, J. (2017). The Last Whalers of the Caribbean. Roads \& Kingdoms. Available online at: https://roadsandkingdoms.com/2017/the-last-whalers- ofthe-caribbean/ [accessed on Jan 14, 2021].

Price, W. S. (1985). Whaling in the Caribbean: Historical Perspective and Update. Rep. Int. Whal. Commiss. 35, 413-420.

Rack, R. S. (1952). Black-fish hunting off St. Vincent. Caribbean Commission Central Secretariat, Trinidad: Caribbean Commission, 80-83

Rappaport, R. A. (1967). Ritual Regulation of Environmental Relations among a New Guinea People. Ethnology 6, 17-30. doi: 10.2307/3772735

Reeves, R. R. (2002). The Origins and Character of 'Aboriginal Subsistence' Whaling: a Global. Mamm. Rev. 32, 71-106. doi: 10.1046/j.1365-2907.2002. 00100.x

Reeves, R. R. (2005). "Insights on Marine Mammals of the Wider Caribbean Sea Region (Including the Gulf of Mexico) Derived from Whaling Documents," in Paper Presented at the Regional Workshop of Experts on the Development of the Marine Mammal Action Plan for the Wider Caribbean Region, (Minneapolis, MN: Milkweed),

Reeves, R. R., Swartz, S., Wetmore, S. E., and Clapham, P. J. (2001). Historical occurrence and distribution of humpback whales in the eastern and southern Caribbean Sea, based on data from American whaling logbooks. J. Cetacean Res. Manag. 3, 117-129.

Robards, M. D., and Reeves, R. R. (2011). The Global Extent and Character of Marine Mammal Consumption by Humans: 1970-2009. Biol. Cons. 144, 2770-2786. doi: 10.1016/j.biocon.2011.07.034

Romero, A. (2012). "Yankee Whaling in the Caribbean Basin: Its Impact in a Historical Context," in New Approaches to the Study of Marine Mammals, ed. A. Romero, (Croatia: InTech), 223-232.

Romero, A., and Cresswell, J. (2005). "In the Land of the Mermaid: How Culture, not Ecology, Influenced Marine Mammal Exploitation in the Southeastern
Caribbean," in Environmental Issues in Latin America and the Caribbean, eds A. Romero, and S. E. West, (New York: Springer), 3-30. doi: 10.1007/1-40203774-0_1

Romero, A., and Cresswell, J. (2010). Deplete Locally, Impact Globally: Environmental History of Shore-Whaling in Barbados, W.I. Open Conserv. Biol. J. 4, 19-27. doi: $10.2174 / 1874839201004010019$

Sakakibara, C. (2020). Whale Snow: Iñupiat, Climate Change, and Multispecies Resilience in Arctic Alaska. Tucson, AZ: University of Arizona Press.

Sauer, C. O. (1966). The Early Spanish Main. Berkeley, CA: University of California Press.

Scott, N. M. (1995). The Current Status and Management Options for the Mammalian Fishery in Barrouallie, St. Vincent, West Indies. Ph D. thesis, University of the West Indies: Cave Hill, Barbados.

Spong, P. (2007). IWC 59 Wrap-up: Rays of Light for Whales. Sea Shepherd Commentary. Available online at: https://www.seashepherd.org.uk/ commentary/archive/page- $45 . h$ tml [accessed on Nov 30, 2020]

Starbuck, A. (1878). History of the American Whale Fishery from Its Earliest Inception to the Year 1876. Washington, DC: US Government Printing Office.

Stevick, P. T., Bouveret, L., Gandilhon, N., Rinaldi, C., Rinaldi, R., Broms, F., et al. (2018). Migratory destinations and timing of humpback whales in the southeastern Caribbean differ from those off the Dominican Republic. J. Cetacean Res. Manag. 18, 127-133.

SVG [Government of Saint Vincent and the Grenadines], (2003). Statutory Rules and Orders 2003, no.42. Washington, D.C: Government Printing Office.

SVGEF [St. Vincent and the Grenadines Environmental Fund], (2019). Marine Conservation: Supporting Whale and Dolphin Conservation in Bequia and Barrouallie. Available online at: https://www.svgef.org/grants/supportingwhale-and-dolphin-conservation-in-bequia-and-barrouallie/ [accessed on Dec 30, 2020]

Swartz, S. L., Cole, T., McDonald, M. A., Hildebrand, J. A., Oleson, E. M., Martinez, A., et al. (2003). Acoustic and visual survey of humpback whale (Megaptera novaeangliae) distribution in the eastern and southeastern Caribbean Sea. Carib. J. Sci. 39, 195-208.

True, F. W. (1904). The Whalebone Whales of the Western North Atlantic. Washington, DC: Smithsonian Institution.

van Tussenbroek, B. I., Arana, H. A. H., Rodríguez-Martínez, R. E., EspinozaAvalos, J., Canizales-Flores, H. M., González-Godoy, C. E., et al. (2017). Severe impacts of brown tides caused by Sargassum spp. on near-shore Caribbean seagrass communities. Mar. Pollut. Bull. 122, 272-281. doi: 10.1016/ j.marpolbul.2017.06.057

Ward, N. (1987). The Whalers of Bequia. Oceanus 30, 89-93.

Ward, N. (1995). Blows, Mon, Blows! A History of Bequia Whaling. Woods Hole, MA: Gecko.

Watson, P. (2012). The Party Is Getting Old in Panama. Sea Sheph. Conservation Society. Available online at: https://seashepherd.org/2012/07/03/the-party-isgetting-old-in-panama/ [accessed on Nov 30, 2020].

Weston, T. (2014). ). The Wind That Blows: A Portrait of the Last Yankee Whalers. Bequia: Grenadines Motion Picture Company.

Wing, E. S., and Reitz, E. J. (1982). Prehistoric Fishing Economies of the Caribbean. J. N. World Archaeol. 5, 13-32.

Wootson, C. R. Jr. (2017). Whale-Watchers Horrified to Witness Fishermen Harpoon Two Orcas. Washington, D.C: Washington Post.

Zerner, C. (1994). Through a Green Lens: the Construction of Customary Environmental Law and Community in Indonesia's Maluku Islands. Law Soc. Rev. 28, 1079-1122. doi: $10.2307 / 3054024$

Conflict of Interest: The authors declare that the research was conducted in the absence of any commercial or financial relationships that could be construed as a potential conflict of interest.

Copyright (c) 2021 Fielding and Kiszka. This is an open-access article distributed under the terms of the Creative Commons Attribution License (CC BY). The use, distribution or reproduction in other forums is permitted, provided the original author(s) and the copyright owner(s) are credited and that the original publication in this journal is cited, in accordance with accepted academic practice. No use, distribution or reproduction is permitted which does not comply with these terms. 